\title{
On Work Relevance of Adult Education: A Case Study Narrative
}

\author{
Tone Vold ${ }^{1,2}$, Hanne Haave ${ }^{2}$ and Aristidis Kaloudis ${ }^{1}$ \\ ${ }^{1}$ NTNU, Norway \\ ${ }^{2}$ INN, Norway \\ Tone.vold@ntnu.no \\ Tone.vold@inn.no \\ Hanne.haave@inn.no \\ Aristidis.kaloudis@ntnu.no \\ DOI: 10.34190/EJKM.18.02.002
}

\begin{abstract}
There is an increased focus on relevance of higher education. Mostly it is about enhanced job opportunities or job advancements for the individual. However, relevance of higher education may also be towards solving important issues or problems at a workplace. There are some necessary preconditions as to how an educational activity becomes relevant. Firstly, the student must be capable to discover how generic knowledge and acquired skills may or may not apply to concrete situations at work. This requires experience, understanding of the norms and culture of the organisation and a certain form of practical intelligence. Secondly, the conditions at work place must be conducive to innovation and change in various ways. In this article, we present a case study where employee turnover and lack of effective training routines were a major efficiency constraint in a Norwegian firm. With constant competition, changes in markets and other factors that influence the sustainability of an organization, cutting costs, such as high turnover and the time from being newcomer to being fully operative in the job. The responsible for training activities in the firm realized that additional formal education at the higher education level was needed, and he decided to enrol in a Knowledge Management study program at The Inland Norway University of Applied Sciences in order to learn how he could improve knowledge management and learning processes of new employees at his workplace. The case study ultimately demonstrates how crucial the interplay between content and form of education on one hand and specific conditions facilitating changes and improvements at work on the other is for the relevance in formal higher education narrative.
\end{abstract}

Keywords: knowledge management, relevance of education, organizational learning, adult learning

\section{Introduction}

One of the salient debates in higher education is the promotion of what is dubbed as "relevance skills". Relevance, a concept that has been marshalled from several disciplines in order to counter a significant antinomy/tension in the pursuit of current educational trajectories between market and institutional orientations.

In this paper, we sought to investigate the issue of "relevance" in a specific epiphenomenon, namely, a qualitative case study of organizational work relevance in Norway. The reason that motivated our case study choice is two-fold. First, the undertheorized state of the debate. As several scholars have argued, relevance is a fuzzy and unclear notion that combines competing elements of utility, skill acquisition, innovative thinking, and motivational resilience. The second reason for our case study choice is the specific national context of Norway, and the fringe character that such organizational studies have traditionally been restricted to in the bibliographical landscape.

The contribution of this paper rests on showcasing the relevance of adult higher education for the enhancement of the participants' work-life prospects. To be sure, this relevance is conditioned on the interplay of employee innovation abilities and innovation capacity of his-her organization. Understanding key aspects of this interplay is the main objective of this paper.

The empirical evidence of the paper is derived from a single, in-depth qualitative case study in four stages, chronologically taking place from 2016 until 2019. The main informant of this case study was appointed to be the head of a new training programme at his workplace in order to address the problem of high turnover and long training periods of new employees. He decided to participate in an educational programme on knowledge management that would enable him to be in a position to effectively fulfil this task with the intention to enhance his-her innovation skills as mandated from the work environment. After the completion of the further education program, the informant applied his newly acquired skills in the task of establishing the new training program at his work. In the subsequent phases the informant assumed different roles in the organization and that had 
consequences for the development of the training programme. In that respect we argue that the acquired educational skills of the informant are in an intimate interplay with the organizational innovation needs and, hence, the relevance of his education skills are conditioned and furthered by the development of the organizational setting. Ultimately, this case study can also cast some light on one of the most persistent problems in organizational studies concerning the rational management of training and turnover costs in organizations.

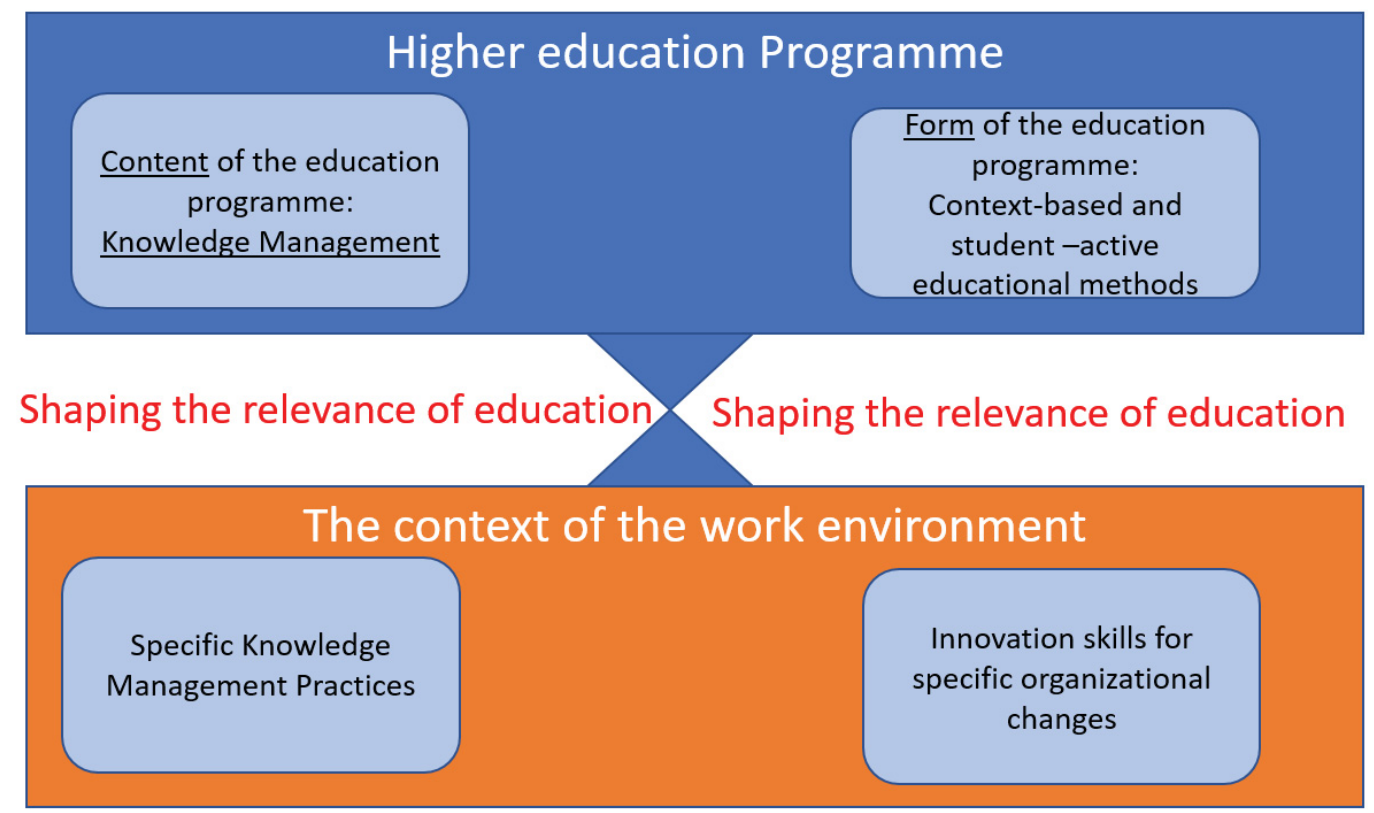

Figure 1: Higher Education Programme - shaping the relevance of education

In the following, we will present the theoretical perspectives that has enlighten our study, before we elaborate on our method of inquiry. Then we present and discuss our findings before we conclude and point the direction forward to future studies.

\section{Theoretical background}

\subsection{What is educational relevance?}

The problem, standardly subsumed under different rubrics such as attrition costs, employment motivation fallouts, job training costs, job mobility costs, employment frictions, is currently ongoing and defies scholarly consensus.

Some organizations are reluctant to spend financial resources on training programs, as other organizations may benefit from the cost of training employees if they decide to resign and join another organization (Darmon 1990), which may be the case for organizations offering a rather generic training programme. For organizations that offer a less generic and more organizational specific program, the time consumption, which is time that the employee is not in operative mode, may also come at a high cost in addition to a high turnover rate (Filstad 2016, Filstad 2017, Filstad and Blåka 2007). The cost of turnover per employee is approximately at least $150 \%$ of the departing employee's pay per year (Hansen 1997).

Studies show that high turnover has a negative effect on productivity and customer outcome, and that it is a significant part of the indirect costs in an organization (Hesford et al. 2016). There are also costs regarding utilizing experienced workforce to train and socialize newcomers when using mentorship training. Until the newcomers are fully proficient, the productivity of the experienced workforce may drop (Hesford et al. 2016) .

To deliberately and willingly leave a company is defined as turnover intention (Mobley 1982). Reasons for leaving may be job satisfaction and the ease of obtaining a new position (Holtom et al. 2008). Job dissatisfaction most certainly reduces employee's endurance in the company, and lead to him or her leaving the organization (Hofaidhllaoui and Chhinzer 2014). Dissatisfaction may be a result of the company's lack of willingness or ability to support the employee to achieve job success and/or handle a stressful work and work environment (Rhoades 
and Eisenberger 2002). Dissatisfaction may also be linked to their work relationship with their mentor; a deteriorating engagement or low degree of support from mentor, can be perceived as a dissatisfactory situation that may lead to considering leaving the organization (Hofaidhllaoui and Chhinzer 2014).

According to Darmon it is vital to recognize the interconnectedness of the "validity and reliability of the recruiting process, the quality and length of the training program and the remuneration level" (Darmon 1990). In other words; the selection of newly recruited employees (hereby newcomers), how the training program support the process of a newcomer becoming full members of the work staff and if they are being rewarded according to their work effort, has impact on the turnover.

Training is one of the key factors for job satisfaction. This training can be job specific or generic and it can be formal, as in formal higher education adult courses, or informal as in intramural mentorships. The formal training may be undertaken in-house or externally (e.g. attending courses at an institution) (Hofaidhllaoui and Chhinzer 2014). In our case study, we have an example of a two-tier training situation; tier one: training of the persons to do a job as front line at the company, and tier two: training the responsible for training the newcomers. For both tiers apply the question of work relevance.

Priniski et al. (2018) have defined relevance as "a personally meaningful connection to the individual". Relevance is personal (personal association), personal usefulness and identification forms a continuum.

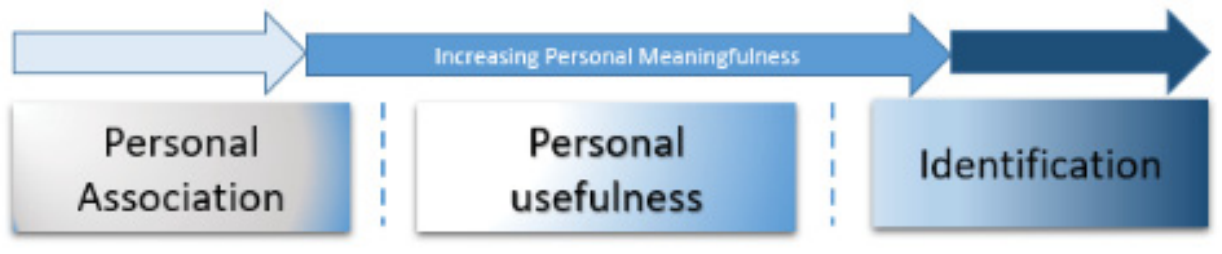

Figure 2: Relevance Continuum (Priniski et al. 2018)

There is thus little doubt that efficient in-house training programs is an important issue for all organisations, it requires careful thinking on what are the basic skills that are needed to be trained and how. Furthermore, it requires planning and systematic as well as cost-effective mobilisation of senior expertise into a learningconducive pedagogical setting at work. Although the organisation of internal training programs at work is not our primary investigation target, the case study we analyse is about the factors determining the relevance of externally acquired advanced knowledge and skills needed to design and develop an effective training program at work.

\subsection{Theoretical perspectives on the relevance of adult training at higher education level}

Teachers can aid students in discovering connections to the classroom material. Then they will be motivated to "engage with the content". Priniski et al. (2018) are looking at how their continuum as a framework to look at motivation literature, in particular three major theories; the four-phase model of interest development by Hidi and Renninger (2006), the expectancy-value theory by Wigfield and Eccles (2000) and self-determination theory by Deci and Ryan (1985).

Hidi and Renninger's (2006) two types of interest; situational and individual, are combined with Priniski et al.'s continuum. Situational interest can be triggered by features within an area of interest. For the Knowledge Management study program - which is a constituent part of our case study - it is possible to envision how the students can gain interest. The first phase can be about the students discovering the connection between the curriculum and their work life. The second phase regards the fact that the attention to the discovery can be maintained by "actively processing" the discovery. Phase three is about the emergent individual interest that in phase four is a well- developed intellectual interest for the individual (Hidi and Renninger 2006). The work during the study program contributes to the process of seeking out what relates to their work situation and how they can solve issues or contribute towards changes at their work place.

Relevance (for the individual undergoing a learning process) appears as triggers in Hidi and Renninger's model (2006) and can be any of the types of relevance in Priniski et al.'s continuum. The personal association is to their work situation and issues at their work place. The personal usefulness also come with an understanding of how they can utilize the new knowledge in their own work situation. They may also be able to identify with the issues 
taught as they recognize situations. Priniski et al. (2018) claim that relevance and interest can coincide and, if so, they mutually reinforce each other. The perceived relevance may lead to situational interest and when this occurs, the students exhibit a genuine intellectual interest.

The expectancy-value model of achievement-related choices of Eccles (2000) deals with four different values; intrinsic value, attainment value, utility value and cost value. Utility and attainment are tied to relevance via personal usefulness and identification, opposed to intrinsic and cost values.

Deci and Ryan (1985) explain the self -determination theory with competence, relatedness and autonomy, all of which contribute to well-being. They differentiate between intrinsic and extrinsic motivation and between internal and external regulation. For our informant it is about his motivation to learn about knowledge management. For his colleagues it is about learning to master a job as front line personnel.

Perspectives from Human Psychology is presented by Carl Rogers (1969) and include personal involvement, selfinitiation, pervasiveness, evaluation by the learner and the meaning it presents to the learner. A major point is that learning is an internal process where the learner is in control and a very natural process within each person. This creates a commitment towards the process and outcome (Nonaka 1994). Lindeman (1926) claim that adults motivation to learn is tied to an experienced need or an interest, and that self-directing is deeply founded within the learner. The latter imply a facilitative role with the teacher/lecturer and an approach that embraces mutual inquiry rather than lecturing. As John Dewey (1938) also claimed, experience is an important source for learning. This imply experiential techniques, such as group discussions, problem-solving activities, solving cases, and simulations (Malcolm S. Knowles et al. 2005).

Knowles et al. (2005) suggest facilitating learning through a process model. This model is about preparing the learner, establishing a climate of mutual respect, trust, openness and support, allowing the learner to participate in the planning alongside the lecturer, conducting the programme, and evaluating the programme.

However, to assess the relevance of an educational programme, Donald Kirkpatrick (1998) developed a four level evaluation. The first level is about how the student react to the programme. What do they perceive as negative and positive sides of the programme. The second level is about what the students has acquired from the programme and may include pre-tests and post-tests. The third level is about looking for changes in the behaviour of the student. Lastly, the fourth level is about effects in the organization, such as change in turnover, costs, enhancements in the efficiency of work performance, etc. (Kirkpatrick and Kirkpatrick 2007). It is the latter fourth level effect that consists our key interest in this paper.

\subsection{From the individual learning to the organisational relevance}

The impact in the organization may push the organization towards being a "learning organization". A learning organization is defined as an organization that facilitates learning for all the members and is in a continuous transformation towards meeting their strategic goals (Pedler et al. 1991).

The learner's experiences form a basis for the new learning. If what is learned is confirming prior acquired knowledge, it can be defined as "single loop learning" (Argyris and Schön 1996). Hence, one of the definitions of learning is any process leading to lasting change of capacity with living organisms, which is not just a result of amnesia, biological maturity or ageing (Illeris 2007). The "double loop learning" is thus when learning changes prior perceptions and adds knowledge to prior experiences. In organizations, the single and double loop learning refers to similar issues; the single loop is about learning to handle returning issues or problems, the double loop is about learning what causes it and it can be about changing goals, strategies, work forms, etc. in order to learn how to avoid the issue/problem.

The experiential approach to learning can be through lab work, simulations, or other situated learning situations (Lave and Wenger 1991). Experiential learning has been described by David Kolb (1984). In an educational setting, concrete experience may come from simulations, case studies, etc. The observations and reflection can be done in groups via discussions, etc. The abstract conceptualization is about combining the new learning to previous experiences, patterns and theories. Then the new concept needs to be tested through new experiences. 


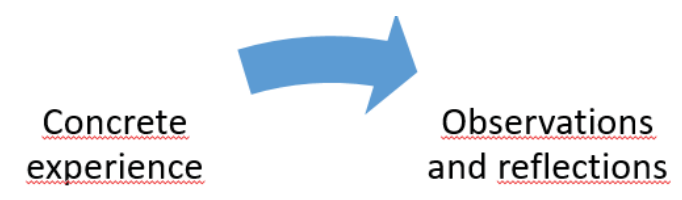

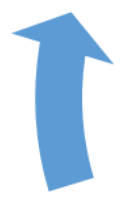

Testing

implications of

concepts in new situations and reflections

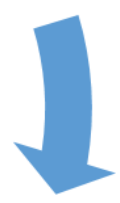

$$
\begin{aligned}
& \text { Formation of } \\
& \text { abstract } \\
& \text { concepts and } \\
& \text { generalizations }
\end{aligned}
$$

Figure 3: Kolb's experiential learning cycle

The experiential learning, as most learning, requires reflective thinking. Reflection may be done prior to an experience (Cowan 2006), during and after an experience (Schön 1987, Schön 1991). It is also possible to extend the reflection to support an enhanced perception of what is learned and to expand the possibilities of utilization (Vold 2011).

In a workplace learning environment, the reflection process may or may not be a part of a standard work procedure, while in an educational setting reflection is a result of how the curriculum is taught (Raelin 2012). Reflection provides a "bridge" between knowledge and learning (Filstad and Blåka 2007). To enhance and stimulate reflection skills in educational programmes is therefore important (Verpoorten et al. 2012), since reflection takes time, and since time is often in short supply in day-to-day activities within organizations (Raelin 2002). The difference between formal and informal/incidental learning is that formal learning in general is classroom-based and structured, whereas informal may be due to "learning by doing" or by mentorship training (Marsick and Watkins 1999). The point to make here is that reflective learning activities are easier to generate in adult educational settings outside the organization, provided that the teaching methodology in these extramural settings systematically cultivates context-based reflexive learning processes.

When learning through experiencing is the means to organizational changes, it is important to share "mental models" (Senge 1992) in order to avoid members of the organization obstructing change. To establish "shared visions" is also important, as this will aid the process of the joint work to pull in the same direction as an organization (Senge 1992). In organizations, one can learn in teams (Senge 1992) or in Communities of Practice (Lave and Wenger 1991).

\subsection{Summarising the theoretical argument:}

Work relevance as a concept is inextricably intertwined with the notions "organizational learning" and "individual learning". These notions are in themselves containers for connected theories. In the following table we show how the concepts used in this chapter is connected and examples (not an exhausting list) of references are given. 
Table 1: Overview of theoretical perspectives, key concepts and examples of references

\begin{tabular}{|c|c|c|}
\hline Theoretical perspective & Key concepts & References \\
\hline \multirow[t]{2}{*}{ About the concept of relevance } & $\begin{array}{l}\text { Organizations willingness to } \\
\text { spend resources on training } \\
\text { programs }\end{array}$ & $\begin{array}{l}\text { Darmon (1990) } \\
\text { Filstad (2016), Filstad (2017), } \\
\text { Filstad and Blåka (2007). } \\
\text { Hansen (1997). }\end{array}$ \\
\hline & $\begin{array}{l}\text { Connection between training } \\
\text { processes and high turnover }\end{array}$ & $\begin{array}{l}\text { Hesford et al. (2016) } \\
\text { Mobley (1982) } \\
\text { Holtom et al. (2008) } \\
\text { Hofaidhllaoui and Chhinzer (2014) } \\
\text { Rhoades and Eisenberger (2002) }\end{array}$ \\
\hline $\begin{array}{l}\text { Relevance of adult training at } \\
\text { higher education level }\end{array}$ & $\begin{array}{l}\text { Motivation for and interest of } \\
\text { learning, relevance of curriculum } \\
\text { to work life }\end{array}$ & $\begin{array}{l}\text { Priniski et al. (2018) } \\
\text { Hidi and Renninger (2006) } \\
\text { Wigfield and Eccles (2000) } \\
\text { Eccles (2000) } \\
\text { Deci and Ryan (1985) }\end{array}$ \\
\hline $\begin{array}{l}\text { Assess the relevance of an } \\
\text { educational programme }\end{array}$ & Four level evaluation & $\begin{array}{l}\text { Kirkpatrick (1998) } \\
\text { Kirkpatrick and Kirkpatrick (2007). }\end{array}$ \\
\hline \multirow[t]{4}{*}{ Organizational learning } & $\begin{array}{l}\text { Facilitate learning for all the } \\
\text { members, learn from experience }\end{array}$ & $\begin{array}{l}\text { Pedler et al. (1991) } \\
\text { Argyris and Schön (1996) } \\
\text { Illeris (2007) }\end{array}$ \\
\hline & $\begin{array}{l}\text { The experiential approach to } \\
\text { learning }\end{array}$ & $\begin{array}{l}\text { Lave and Wenger (1991). } \\
\text { Kolb (1984). }\end{array}$ \\
\hline & Reflection & $\begin{array}{l}\text { Raelin (2012). } \\
\text { Verpoorten et al. (2012) } \\
\text { Marsick and Watkins (1999) }\end{array}$ \\
\hline & $\begin{array}{l}\text { Share mental models by team } \\
\text { learning or Communities of } \\
\text { Practice }\end{array}$ & $\begin{array}{l}\text { Senge (1992) } \\
\text { Lave and Wenger (1991) }\end{array}$ \\
\hline \multirow[t]{3}{*}{ Individual learning } & $\begin{array}{l}\text { Learning as an internal process } \\
\text { that creates a commitment } \\
\text { towards the process and outcome }\end{array}$ & $\begin{array}{l}\text { Rogers (1969) } \\
\text { Nonaka (1994) }\end{array}$ \\
\hline & $\begin{array}{l}\text { Experience is an important source } \\
\text { for learning. }\end{array}$ & $\begin{array}{l}\text { Lindeman (1926) } \\
\text { Dewey (1938) } \\
\text { Kolb (1984) }\end{array}$ \\
\hline & $\begin{array}{l}\text { Facilitating learning through a } \\
\text { process model }\end{array}$ & Knowles et al. (2005) \\
\hline
\end{tabular}

\section{Methodological approach}

We adopt a case-study analytical framework with an action research approach. The primary aim of our study is to discuss aspects and degrees of relevance of a specific formal higher education program for adults on Knowledge Management in a specific work place context. We develop the so-called thick descriptions of the case and the situation (Geertz 1973, Remenyi 2012), which help us to disentangle various dimensions and determine degrees of "relevance" of the educational stimuli received by the student at his workplace.

We have followed a former student of a Knowledge Management study programme at his workplace through a period of time from 2017-19 (prior to this there are field notes from the study program starting autumn 2016), and investigated the organization's processes and experiences on developing their mentorship training programme. The informant (hereafter called Student X) was first selected, as he was a student at a Knowledge Management study programme where one of the authors was lecturing. Another important criterion for choosing this particular informant was that he had a job where he was responsible for developing a Knowledge Management initiative (the mentoring programme). This mentoring programme offers a good empirical base to investigate the relevance of a specific Knowledge Management -education setting to work life.

The company is a small/medium size organization located south of the capitol of Norway, Oslo. They operate in a market with heavy competition. They are classified as service providers, with the main work done at the company being customer contact. Their aim is to be able to answer, and help, all customers who contact them every day. 
Our first study in 2017 was a pilot study with Student X as our only informant. In 2019, we made two follow-up visits to the company to investigate what type of impact the mentorship-training programme was having on the firm.

The data was collected by doing semi-structured in-depth individual interviews with targeted employees of the firm. It was important to interview employees with different roles and experiences from the apprenticeship programme; this included two apprentices and two mentors, as well as interviews with the manager and the other team coordinators. The informants were selected by the organization, and this may have influenced the character of our data, as they expressed a positive attitude towards the changes. A broader variety of respondents may have provided us with different perspectives.

When visiting the premises of the firm, we observed how the workplace was organized, and got an impression of the atmosphere in the organization, in addition to talking to the employees. When collecting the data, we focused on capturing the informants' understanding of the organizational events, what they claim were their experiences and what they learned from it. As researchers, we have had different roles, both the role of being more distant from outside researchers, while at other times taking a more active part in the processes. When first visiting the firm, we agreed beforehand with management that we would report on our findings and make propositions as to how they were to manage their mentorship-training programme (onboarding). Therefore, after doing interviews and getting the experiences, we prepared a report with suggestions as to how we thought the company should take action on developing a plan for securing their onboarding programme. This was developed from the experiences and suggestions of improvements from the employees, as well as our views on the matter. This applies to a more co-generative action research model (Greenwood and Levin 2007).

Table 2: Table showing informants

\begin{tabular}{|l|l|}
\hline Informants & Role of the informant \\
\hline Student X & Main informant/Respondent 1 \\
\hline The CEO of the company & Respondent 3 \\
\hline Three mentors & Respondent 4,5,6, \\
\hline Three newcomers & Respondent 7,8, 9 \\
\hline Member of the top management & Respondent 2 \\
\hline
\end{tabular}

Table 3: Table showing when the different research material was collected and type of data material

\begin{tabular}{|c|c|c|}
\hline Phase & Occasion & Research material \\
\hline Phase $1(2016 / 2017)$ & In class: Field notes & Teachers notes \\
\hline Phase 2 (2017) & $\begin{array}{l}\text { Phone interview: } \\
\text { Interview with Student X }\end{array}$ & $\begin{array}{l}\text { Teacher notes } \\
\text { Phone }\end{array}$ \\
\hline Phase 3 (2018) & Phone interview & Notes from phone interview \\
\hline Phase $4(2018,2019)$ & $\begin{array}{l}\text { Skype meeting: } \\
\text { Interview with Student X, and } \\
\text { respondent } 1 \\
\text { Meeting } 1 \text { at company: Interview } \\
\text { with Student X (1) } \\
\text { Interview with CEO (3) } \\
\text { Interview with colleague } 1(2) \\
\text { Interview with mentors }(4,5) \\
\text { Interview with newcomer }(7,8) \\
\text { Meeting } 2 \text { at company: } \\
\text { Interview with Student X (1) } \\
\text { interview with Mentor }(6) \\
\text { Interview with Newcomer (9) }\end{array}$ & $\begin{array}{l}\text { Skype, recording, notes } \\
\text { Field notes } \\
\text { Recordings and field notes }\end{array}$ \\
\hline
\end{tabular}

We have analysed these interviews based on our theoretical foundation set out in the previous section.

\subsection{Presentation of the case study}

The narrative of this case study commences with the primary informant (Student X), and explores how he applied formal education-learned skills in the organization of which he is today an employee. The other informants in the case study are eight of his colleagues in the firm: the CEO, the management team, three mentors and three newcomers. The organization is a part of a larger Scandinavian company. The company is a small to mediumsized service provider in a very competitive market of automobile services. The staff of the company usually receives in-house training with regard to how to meet customers, and how to effectively perform company- 
specific tasks. The customers are divided into two tiers: Tier 1 are the companies that purchase services from "our" service provider company, whereas Tier 2 are the paying customers of Tier 1 that need services from "our" company. The front-office workers and their supervisors are the ones dealing with the Tier 2 customer type, while the managerial team deals with Tier 1 customers. It is not unusual that some of the members of the management team are recruited from among the most experienced front-office employees.

The narrative of our case study consists of four distinct phases in chronological order over three years: a) The student participates in the study programme, Knowledge Management at The Inland Norway University of Applied Sciences. Student $X$ utilized the opportunity to use the organization he worked for as a case in his education. He also established a good communication with the teachers/lecturers at the study programme, with his managers permitting him to use the organization in his assignments. They also appreciated the feedback provided by the lectures; b) Phase 2 is the period when the student returns back to his working environment and successfully initiates a project of co-developing a mentoring programme (a bottom-up process). Student $\mathrm{X}$ used what he had learned about how adults learn, and how they gain commitment to a process. Instead of him dictating how the training was to be developed and executed, he involved the potential mentors in a development process. Together, they formed the mentorship programme. The programme was initiated and the ones assuming mentor roles did this as volunteers; c) Phase 3 is the period when the mentoring programme stagnates. Student $X$ is reassigned to other tasks, and a person in top management is now the new one responsible for the training programme. The work tasks change, but the mentors do not receive any further training. Hence, they are not providing any updated information to the newcomers. And lastly, d) Phase 4 is the period where the mentoring programme is reintroduced and reshaped, this time as a top-down process but with the acceptance and involvement of the employees, and with the previous student employee now in the management team of the company, as shown below in Figure 4.

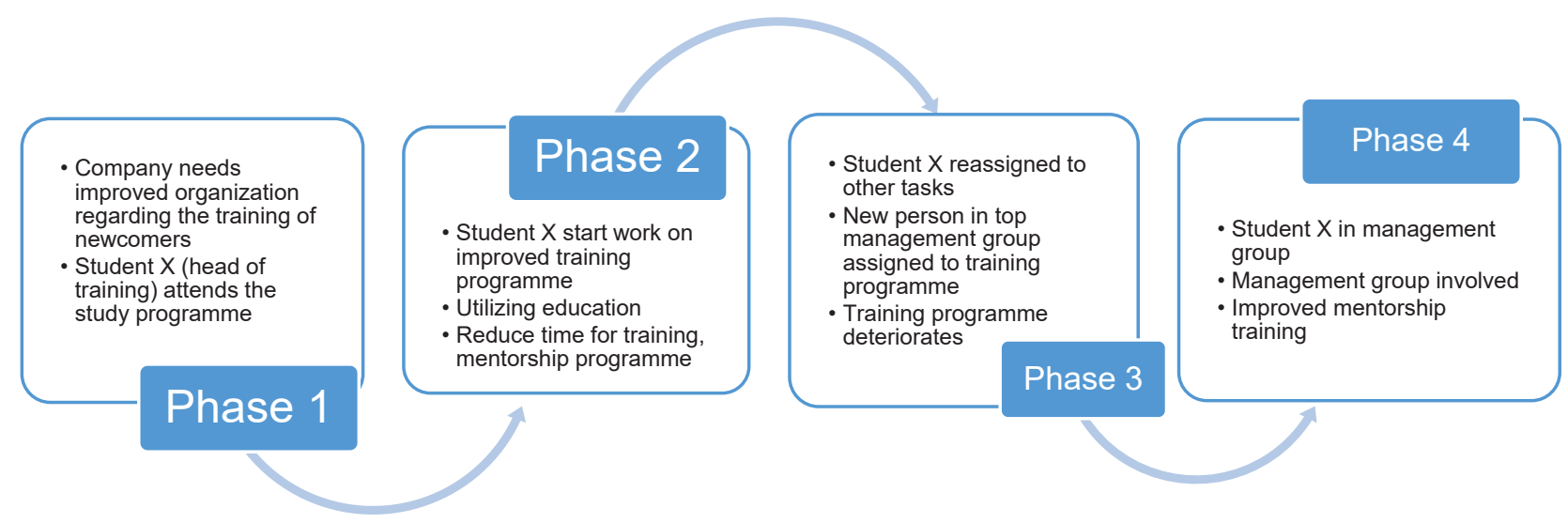

Figure 4: The four phases of the development in the case study

\section{Main findings}

In this section, we present in greater detail the key elements of the case study in a chronological order, see Figure 4.

\subsection{Phase 1}

Student $X$ has been appointed as responsible for the training program of all newcomers. He very soon realized that he lacked knowledge about how to organise adequate training programme activities. He succeeded to persuade his superiors to let him attend a formal higher education study programme on Knowledge Management. He got permission from both the lecturer and the company to use his work at the company as a basis for his course assignments. Student $X$ was an interested and active student in the class (Haave and Vold 
2018). Field notes show that he approached the lecturers early in the first semester to discuss different issues at his company.

At the same time as Student $X$ attended the Knowledge Management study programme, there was a project going on at his work place regarding testing out different approaches to involving and engaging students. Several times during the two semesters, the lecturer deliberately employed case of a company similar to where Student $X$ works.

\subsection{Phase 2}

After the end of the study programme, Student $X$ started his work on the new training programme. He claimed to have "the schoolbooks under his arm", and making active use of skills acquired during his studies as he organized bringing his colleagues in to the work of developing the new training programme. He claimed that his colleagues contributed to a new training programme that in practice was a mentorship programme. The mentors had volunteered and assumed the responsibility of "apprentices", even if this meant extra work. He organized things with top management so that every so often during company meetings the mentors received "extra tickets to the wine lottery". They also got signed confirmations that they were mentors.

Student $X$ says in the same interview that the results were noticeable. The newcomers were operable after approximately two-three weeks, as opposed to six months on average before the introduction of the new training mentoring programme. According to Student $X$, the managerial team of the company stated their satisfaction with the new programme, as they were "impressed". They also recognized the positive economic impact of the new programme. Table 4 exhibits key indicators (provided by Student X) regarding the effects of the new training program on training time and on turnover of employees.

Table 4: Overview of factors contributing to reduce costs for the company

\begin{tabular}{|l|l|l|}
\hline & $\mathbf{2 0 1 8}$ & $\mathbf{2 0 1 9}$ \\
\hline Turnover & Approx. 20\% of newcomers & Approx. 5\% of newcomers \\
\hline Training time & Approx. 6 months & Approx. 21 days \\
\hline
\end{tabular}

One of the colleagues of Student X (informant 3) referred to him as, after the completion of his training in Knowledge Management, as being able to present projects in plenary and make himself heard. The colleague recognized the ability of Student $X$ to engage people in structured discussions that eventually led to improvements in the implementation of the new programme. This is one example of his ability to make the colleagues come up with the idea of a mentorship and how to execute it.

\subsection{Phase 3}

Student $X$ got recognition for his work and was given other tasks in the company. In the 2018 interview, he claimed that he was given other tasks due to his successful work on the new training programme. For the same reasons, the management of the training programme was now delegated to another employee who did not have to take part in the previous developments and evolution of the training programme; he did not receive training in Knowledge Management as Student $X$ did, and had additional responsibilities for other tasks that were also prioritized in the company. According to interview statements: “... it [the training programme] was a huge success. Worked very well. But it did not last.... they were not involved in the process. They had no commitment."

According to Student $X$, the training programme was not developed further nor followed up in what he would describe as "a proper way". Student X claimed that "the knowledge of the mentors became outdated, and that they were still teaching newcomers 'old news'". According to Student X, this did led to a prolonged training period for the newcomers, as both the mentors and the newcomers needed to revise their knowledge in order to provide the correct aid to their customers. This may have been due to a lack of updating of the mentors, and that the mentors seemed "on their own" with little or no follow up from management. This again may be due to management's lack of understanding of the work area, not the explicit parts, but maybe the more subtle, tacit areas of the work of the ones executing the customer service. Statements from our interviews that support this are: ".. the head of the assistance centre at the time had worked in [the company (anonymized)] for a few years, but only as a manager, right, never answered a telephone, never worked with it [note from authors: here meaning the work that is going on at the shop floor level]. And we had three team leaders that were also hired from outside. And together, the four did not do a good job. It was actually a disaster. It went really bad. We lost 
a lot of good co-workers [.... It turned out to be expensive." and "...and when I got a new position and someone else was to take over, then it was... they found their own ways, even if I gave them my things, right, that were not rooted in the leadership."

\subsection{Phase 4}

In this phase, Student $X$ got a position in top management. He was also reassigned to the task of running the training programme, as most of the management group were not working there any longer, including his predecessor, the person who took over the responsibility to manage the training programme in Phase 3. After assessing the state of the training programme, he understood that it needed to be radically revised.

According to him, and confirmed in interviews with the current top management group (respondent 2 and 3 (see Tables 2 and 3)), he was careful to involve both the top management group and the existing mentors in the development of a new and revised training programme.

Student $X$ succeeded to once again restructure the training programme by involving and engaging the top management and the workers in the company. The top manager and the management group confirmed their involvement and commitment. This was further confirmed when one of the colleagues in the management group developed the presentation for the new training programme. Student $X$ states this explicitly in the last interview: "...It is [respondent 1 (see tables 2 and 3)] that has made the PowerPoint presentation, by the way. Has agreed about different things. So then all of us have some ownership towards it then, so it becomes very much better than when it was only me having a project on the side". The confirmation of obtaining a commitment that Student $X$ wanted to establish in the top management group was presented with this statement: "It did not get real until [respondent 1] made the presentation for the new staff."

The establishment of the new and improved training programme was introduced and Student $\mathrm{X}$ remarked on the difference in the top-down versus the bottom-up processes: "It was easier when I was a part of the top management group." They also evaluate their different approaches to training, and have won prizes for excellent customer service, including an award for best call centre (translated from Norwegian: Kundeserviceprisen - årets kundesenter) that they refer back to as an effective method for training the staff.

In Phase 4, the top management group is looking to improve the training and adapt training, both with more specific training and looking towards more digitalized solutions such as e-learning, games for learning, simulations and Augmented Reality/Virtual Reality. Student X proclaims: "Now we are always looking to improve the training."

Another reflection by Student $X$ was about how his educational background (with reference to the Knowledge Management education programme) has influenced the trajectory of the company's training programme: "Having worked my way up, I have an understanding of what it takes to get up to speed."

\section{Discussion}

In this section, we discuss findings regarding the work relevance of higher education. The theory we have chosen to illuminate our study emphasizes two aspects: 1 ) individual learning as a precondition regarding the relevance of the education for the specific firm; and 2) the organizational readiness to organizational learning.

\subsection{The individual learning process}

The individual learning process commences with Student $X$ and his participation in the Knowledge Management course offered by the Inland Norway University of Applied Sciences in 2016/2017. In Phase 1, Student X gets permission to participate in the Knowledge management study programme. His engagement in class shows that he is eager to understand and learn about the theory in order to apply it in his organization. He promotes his company as a case for the class to discuss, and is actively involved and engaged in the discussion, in line with what Knowles (Knowles 1970, 1990) describes as important regarding adult learning. Personal involvement, selfinitiation and pervasiveness are key elements of learning according to Rogers (1969). It is also important that the learner has a sense of the learning corresponding with his or her personal needs, and providing a sense of relevance and identification (Priniski et al. 2018). 
Student X's story about how he "brought his curriculum books back to the organization" in Phase 1, and started the work on including his colleagues in developing what was to become a mentorship training for newcomers, is an indication of the significance of his own learning process and his determination to utilize his new knowledge in the workplace. This understanding of adult learning principles is prominent when he allows his colleagues to come up with ideas for the new training programme, instead of dictating what is going to be the new solution. He allows and encourages an involvement in order to create an engagement and commitment among the potential mentors.

His approach to experiential learning follow the described experiential learning cycle as he starts the active experiencing testing out how his new knowledge (of adult learning principles), he reflects on how this turned out, then he shares his knowledge before he bring the new learning into practice through new active experiencing (Kolb 1984).

The groups has a resemblance to Communities of Practice (Lave and Wenger 1991) as there are persons that are more skilled and thus the colleagues will have differences in their legitimate peripheral participation.

In Phase 4, we recognize the same approach with his colleagues in the top management group. He is able to involve them in his thinking and development of plans for the renewed training programme. The clearest sign of success is when a member of the top management group is the one designing the new start-up of the training. He also showed an eagerness regarding the didactic methods we used during the study programme. In this process, knowledge sharing was very important to our student, and he utilized the very methods used in the Knowledge Management study programme in order to support the work on organizing the work that would lead to a mentorship programme for the newcomers. This changed his experiences and led to a double loop learning process (Argyris and Schön 1996) as he learned new ways to engage and involve his colleagues (Argyris and Schön 1996) (Malcolm S. Knowles et al. 2005) .

\subsection{The application of learning - designing the mentoring programme}

The understanding of devising processes to include and involve his colleagues in the work of developing a new training programme shows how he made the relevance of both the content and form of the Knowledge Management study programme. His aim was that the potential mentors should have a strong commitment to the mentoring programme (Nonaka 1994). Because there were no personal benefits tied to the new organization of training newcomers, it was important for him to secure the mentors contribution and commitment to the new regime. In the first interview with him in 2017, he reported that the introduction of mentorships had been successful (Haave and Vold 2018).

Student $X$ focuses his attention on both learning in teams and learning individually. The team learning (Senge 1992 ) is in the very beginning of the training programme. Here, the company is also very aware about making the newcomers share their vision about the company and their work. To obtain personal mastery (Senge 1992), the training programme is designed to have a mentorship programme. Student $X$ show an understanding of the system this forms by the way he first manages to introduce this learning programme as a bottom up process in Phase 2 , and later reintroduces it, this time as a top-down process, while still maintaining the various disciplines.

\subsection{The stagnation process}

The training programme is recognized and the responsibility is elevated to the top management group. Student $\mathrm{X}$ is assigned to other tasks, probably as a promotion due to his success. The new person responsible for the training programme does not follow it up, and it stagnates and the newcomers are even taught elements that are out of date. One explanation for this is that the new person responsible does not assume a commitment to the task (Nonaka 1994). As this person is delegated someone else's success, having had little or nothing to do with the development, it is reasonable to assume that coupled with other possibly more exciting or pressing job tasks, this will be not be prioritized and thus left "on its own".

\subsection{The reinvigoration of the mentoring programme and its perceived effects}

There are dramatic changes made in the organization, and a new top manager is hired. His top management group is now requited among the persons who have been a part of the workforce for some years and that have advanced, including Student X. (The former responsible for the training programme is made redundant.) When the "dust settles" it is time for Student X to revise the training programme, as he is reassigned this task. Again, 
he involves his colleagues, this time in the management group and for the future mentors. This can be interpreted as a sign of what Mazlow (1987) refers to as using one's "talents, capacities and potentialities" obtained through education.

What Student $X$ does in both Phases 1 and 4 is coherent with what is suggested regarding adult learning (Knowles 1984, Knowles 1990, Malcolm Shepherd Knowles et al. 2005), including and involving his colleagues in developing the training programme, as well as providing the colleagues with a commitment (Nonaka 1994) towards the training programme and how it will be executed. In the third phase, it is also about how to obtain a commitment among the management group, in addition to a renewed commitment with the colleagues in the "production".

\subsection{Organizational learning}

The organizational learning is dependent on that the individual learn (Filstad 2016, Filstad and Blåka 2007). Student $X$ represents one individual in the organization who has received his knowledge and competence from outside the organization.

We find evidence of both single- and double-loop learning. The single loop is apparent prior to sending Student $X$ to study how to develop training programmes, as they just hired more people when employees quit or were not fully trained to be independent. Solving a recurring problem is classified by Argyris and Schön (1978) as a single loop. Doing something with the fundamental reasons causing the problem is defined as a double loop. This may imply that strategies and even missions and goals need to be revised (Filstad 2016, Jacobsen and Thorsvik 2019). In Phase 1 , by sending Student $X$ to higher education is an example of doing something different to solve the problem, and may be classified as single loop since they still have not revised any strategies, goals or missions. In Phase 2, the strategy for training and learning is changed. The results show a reduction in training time and lower turnover. This implies lower costs for the company (Filstad 2016), as they can handle more work and train less staff.

In Phase 3, they assign the training responsibility to a member of the top management group. This is also an example of a double loop, as this is about changing the priority of the training programme. It is no longer a bottom-up initiative, but instead a top-down responsibility.

In the same phase, the training programme stagnates. The training person responsible in the top management group falls back into a single loop (Argyris and Schön 1978), since he is only interested in solving the short-term problems.

In the $4^{\text {th }}$ phase, the new top manager was reassigned to the task of being responsible for the training of newcomers. This triggered a revision and improvement of the training system. The inclusion of the top management group in this phase is an example of the double loop (Argyris and Schön 1978), as this is about anchoring the process of training newcomers and constantly improving the solutions.

The focus on the continuous improvement and evaluation of the training programmes implies what Flood and Romm (1996) refer to as triple-loop learning. It is important for them not only to constantly change and improve, but also to improve that which will create a better change. To evaluate whether they are "doing the right things" AND "doing the things right" is an indication of the company having entered the triple loop regarding the development of the training programme.

The organization recognized a gap in what they had and what they needed for competencies, as they realized that they experienced high turnover, and that it took up to six months to train a new employee. This is similar to what Lai (2013) explains about learning needs within the "defined requirements for competence". The organization needed to look at ways of reducing costs, with one way being to do something about the recruitment. Hence, they assigned a training person to be responsible. This person recognized a problem with the training system, and saw a need for upgrading his competencies regarding how to share and distribute knowledge within the organization. This was approved by the organization; thus, he attended higher education and the Knowledge Management study programme. This can be recognized as a sign of entering a double loop (Argyris and Schön 1978), as this a way of looking at what needs to be changed in the organization in order to improve a situation. 
In the third phase, the organization saw the need for Student X's competencies in other parts of the organization. Management transferred the responsibility to a member of the management group, which actually brings the responsibility of the training programme to a higher level within the organization. This is an indication of management's acceptance and acknowledgement of the importance of the training programme (Bradt and Vonnegut 2009). However, his replacement, although within the management group, did not have the same commitment. Hence, the mentorship-training programme was given less of a priority. This stands in coherence with the theory on securing commitment to tasks, by including and involving persons in the development process (Filstad 2016, Filstad and Blåka 2007). There also seems to be a lack of a shared vision (Senge 1992) among the members of the organization. A statement that supports this is: “... and when I got a new position and others were to take over, it was... they found their own ways, even if they got my documentation, right, it was not properly founded in the management".

When they employed Student $X$ in the management group and reassigned the training programme to him, they not only required his competency in the management group, but also realized another need: a committed person to be responsible for the training programme. This acceptance resembles an organizational learning process (Pedler et al. 1991). Sending Student X to learn about Knowledge Management processes, and to support his work on co-developing the training programme with his colleagues, can be viewed as a double-loop learning process (Argyris and Schön 1996), as they have realized that their existing training of newcomers is not optimal, and that they need to apply different approaches toward this training. Their willingness to support and fund a bottom-up initiative points in the direction of reframing values, which is a part of the double-loop learning. In Phase 4 the management group has changed, and there is a renewed interest in the task (Filstad 2016, Filstad and Blåka 2007, Irgens 2011). We also find that there is a stronger focus on shared visions and mental models (Senge 1992) regarding the training of newcomers.

In the fourth phase, management even considers not only how to further improve the mentorship training, but also if what they are doing is the right thing. They have also added a new feature to the mentorship training that involves middle management (team coordinators). They are now to report to top management regarding results and experiences from the mentorship training programme. A statement confirming this is: "We will have to do adjustments based on our experiences. And I hope we will continue to do so forever. Make adjustments, that is. To make it dynamic". This is in line with the idea of triple-loop learning, where it is important to constantly improve and also evaluate if one is "doing the things right" (Flood and Romm 1996).

\subsection{Relevance of education}

They discovered a gap in the competence and acted upon this, as they sent the responsible person for training to attend higher education. This formal education contributed to developing and implementing a new training programme.

This training programme turned out to be a success as soon as the responsibility of the training programme was assigned directly to the top management level. However, due to a lack of shop floor experience, he did not assume the commitment was needed. This points towards a reflection on explicit versus tacit knowledge (Nonaka and Takeuchi 1995, Polanyi 1966, Polanyi 1967), as it is suggested that a part of understanding the updating of knowledge that needs to be done is linked to tacit knowledge with the ones who have been in the organization over time.

We have reason to believe that the shop floor experience has turned out to be vital for enhancing the learning culture.

We claim that the organization has developed an ability to cultivate a learning culture and learn by experience, while at the same time evolving and adapting to a changing market. This has also led them to turn to external expertise, as we were invited to comment and suggest improvements to their training programme process. Our suggestions were implemented later on.

The original goal was to develop an effective, efficient and economically viable training programme. Because of the process the company of the case study has gone through, it has gradually become a learning organization according to the definition above. In this process towards becoming a learning organization, we claim that the skills acquired in the Knowledge Management education programme by Student X were instrumental, thereby representing a decisive tool to achieve the initial goal. However, again, in order to achieve the initial goal, the 
entire philosophy of the company towards learning processes had to be changed substantially, and for that, there is a need for innovation skills that relate to their concrete context. They are now "an organization that facilitates the learning of all its members and consciously transforms itself and its context" (Pedler et al. 1991).

\subsection{Limitations}

Our research is based on one case, and more cases would be interesting to follow up. Since we have been able to do a rather close follow-up of the case, this has given us some important indications. However, we cannot discard other possible additional explanations that may surface by investigating more cases.

\section{Conclusions}

We have sought to understand the circumstances a formal education is becoming relevant in work life. According to the definition, relevance is "something serving as a tool to a goal" (Hjørland and Christensen 2002). In our material, we have discovered conditions that we find to be present in order for the organization to obtain its goals regarding the training programme.

Our data indicate the complex interplay between Student X's formal learning of Knowledge Management techniques and skills and changes in the organization of fundamental learning processes within a Norwegian firm. The organization's ability to change can be viewed as a tool for survival in a changing market. The organization has become more adaptive toward changes in the market, and better equipped to withstand competition. This is due to the introduction of a new mentorship programme that since the start has been subject to refinement into a system of continuous improvement. The mentorship programme was developed through an inclusive process enabled by our Student X's innovative skills gained through taking part in a higher education study programme. This process was in line with theories of adult learning and secured involvement and engagement, first among the employees who became a part of the mentorship programme, then among the management group. The latter also contributed towards a commitment from management regarding a continuous improvement. The democratic process is not only the result of the curriculum (content) in the Knowledge Management educational programme, but also to the meta-learning from the course (i.e. to the form of the educational activities in the educational programme employing student active methods).

We have also been able to identify the organization's ability towards embracing the initiative from Student X. The company realized the need for a different training system and allowed the bottom-up initiative, as they recognized the improvement and moved the responsibility to the top management group. Also, the renewing of the training system was initiated as a top-down process, indicating their understanding of its importance to the company.

Having said that, Phases 2 and 3 of this case study show how the relevance of acquired skills is contingent on the understanding and commitment of top management. The organizational ability to have shared visions and common mental models recognizes the importance of personal mastery and team learning, to recognize these factors (disciplines) as a system confirms the organizational consciousness towards learning, and thus, renders "relevant" related innovation skills acquired in formal educational settings.

In other words, we claim to have found important contextual conditions in this work life case that determine the relevance of higher education, both the relevance of its educational content and the form of the educational activities. A fundamental organizational competence that ought to receive more focus in the future is the ability to discover gaps in competence in the organization, the ability to act upon this by acquiring new knowledge or new employees, and letting this knowledge be "put to work" within the organization.

The continuous focus on development for sustainability is highly present. The "tool" was higher education and the "goal" became twofold: originally, it was to develop a training programme, which also resulted in the company becoming a learning organization.

\section{Further research}

It will be interesting to follow the mentoring programme and the organization further, and to observe if their competitive advantage positions will be sustained in the future. Our future research will be to continue following their continuous process to establish whether they are able to maintain the triple loop. 
It will also be interesting to follow up an eventual change in how they train their mentors if they choose to organize this as a separate activity. Will this have any effect on the sustainability of the total mentorship programme?

We also want to expand the number of cases by contacting previous students of the Knowledge Management study programme. This will provide us with an even richer insight of possible relevance of higher education study programmes in work life.

\section{Acknowledgements}

We extend our gratitude to Zacharias Andreadakis, $\mathrm{PhD}$, that has provided us with valuable comments and suggestions to pertinent literature. We also would like to thank two anonymous referees for their valuable comments and constructive suggestions.

\section{References}

Argyris, C. and Schön, D. (1996) Organizational Learning II. Theory, Method, and Practice New York: Addison-Wesley Publishing Company, Inc.

Argyris, C. and Schön, D. A. (1978) Organizational learning : a theory of action perspective, Reading, Mass: Addison-Wesley. Bradt, G. B. and Vonnegut, M. (2009) Onboarding : how to get your new employees up to speed in half the time, Hoboken, N.J: Wiley.

Cowan, J. (2006) On becoming an innovative university teacher: reflection in action, Buckingham: Society for Research into Higher education \& Open University Press.

Darmon, R. (1990) Identifying Sources of Turnover Costs: A Segmental Approach. Journal of Marketing, 54(2), pp. 46.

Deci, E. L. and Ryan, R. M. (1985) Intrinsic Motivation and Self-Determination in Human Behavior, Springer US : Imprint: Springer [online], available: [accessed

Dewey, J. (1938) Experience \& Education, New York: Touchstone.

Filstad, C. (2016) Organizational Learning: - from knowledge to competency (in Norwegian: Organisasjonslæring - fra kunnskap til kompetanse), 2. utg. ed., Bergen: Vigmostad \& Bjørke.

Filstad, C. (2017) Newcomers organizational socialization: perspectives and learning strategies (Translated from Norwegian: Nyansattes organisasjonssosialisering : perspektiver og læringsstrategier), Bergen: Fagbokforl.

Filstad, C. and Blåka, G. (2007) Learning in organizations, Oslo: Cappelen.

Flood, R. L. and Romm, N. R. A. (1996) Diversity management : triple loop learning, Chichester: Wiley.

Geertz, C. (1973) The Interpretation of cultures, New York: Basic Book.

Greenwood, D. and Levin, M. (2007) Introduction to Action Research 2nd ed., Thousand Oaks, California: Sage Publications. Haave, H. M. and Vold, A. T. (2018) Knowledge management in action: A case study from Norway.

Hansen, F. (1997) What is the cost of employee turnover? Compensation and Benefits Review, 29(5), pp. 17-18.

Hesford, J. W., Malina, M. A. and Pizzini, M. (2016) Turnover and Unit-Level Financial Performance: An Analysis of the Costs and Benefits of Voluntary and Involuntary Turnover in Unskilled Jobs. in Malina Mary, A., (ed.) Advances in Management Accounting: Emerald Group Publishing Limited. pp. 35-65.

Hidi, S. and Renninger, K. A. (2006) The Four-Phase Model of Interest Development. Educational Psychologist, 41(2), pp. 111-127.

Hjørland, B. and Christensen, F. S. (2002) Work tasks and socio-cognitive relevance: A specific example. Journal of the American Society for Information Science and Technology, 53(11), pp. 960-965.

Hofaidhllaoui, M. and Chhinzer, N. (2014) The Relationship Between Satisfaction and Turnover Intentions for Knowledge Workers. Engineering Management Journal, 26(2), pp. 3-9.

Holtom, B. C., Mitchell, T. R., Lee, T. W. and Eberly, M. B. (2008) Turnover and retention research a glance at the past, a closer of the present, and a venture into the future. Annals // The Academy of Management, pp. 231-274.

Illeris, K. (2007) How we learn : learning and non-learning in school and beyond, Læring, London: Routledge.

Irgens, E. J. (2011) Dynamic and learning organizations: managment and development in a changing worklife, Bergen: Fagbokforl.

Jacobsen, D. I. and Thorsvik, J. (2019) How Organisations Work (translated from Norwegian: Hvordan organisasjoner fungerer), 5. utgave. ed., Bergen: Fagbokforlaget.

Kirkpatrick, D. L. (1998) Evaluating training programs : the four levels, 2nd ed. ed., San Francisco, Calif: Berrett-Koehler.

Kirkpatrick, D. L. and Kirkpatrick, J. D. (2007) Implementing the four levels: a practical guide for effective evaluation of training programs, San Francisco: Berrett-Koehler Publishers.

Knowles, M. S. (1970) The modern practice of adult education : andragogy versus pedagogy, New York: Association Press.

Knowles, M. S. (1984) Andragogy in action, San Francisco: Jossey-Bass.

Knowles, M. S. (1990) The adult learner: a neglected species, Houston: Gulf Pub. Co.

Knowles, M. S., Holton, E. and Swanson, R. A. (2005) The adult learner: the definitive classic in adult education and human resource development, Amsterdam: Elsevier.

Knowles, M. S., Holton, E. F. and Swanson, R. A. (2005) The adult learner : the definitive classic in adult education and human resource development, Elsevier [online], available: [accessed 
Kolb, D. A. (1984) Experiential learning: experience as the source of learning and development, Englewood Cliffs, N.J.: Prentice-Hall.

Lai, L. (2013) Strategic Competence Management (from Norwegian: Strategisk kompetanseledelse), Bergen: Fagbokforl.

Lave, J. and Wenger, E. (1991) Situated learning - Legitimate peripheral participation, Cambridge: Cambridge University Press.

Lindeman, E. C. (1926) The meaning of adult education / by Edward C. Lindeman, The meaning of adult education / by Edward C. Lindeman, New York: New York, New Republic.

Marsick, V. J. and Watkins, K. E. (1990) Informal and incidental learning in the workplace, International perspectives on adult and continuing education, London: Routledge.

Marsick, V. J. and Watkins, K. E. (1999) Facilitating learning organizations: making learning count, Aldershot: Gower.

Maslow, A. H. (1987) Motivation and personality, 3rd ed. ed., New York: HarperCollins.

Mobley, W. H. (1982) Employee turnover : causes, consequences, and control, Managing human resources, AddisonWesley.

Nonaka, I. (1994) A Dynamic Theory of Organizational Knowledge Creation. Organization Science, 5(1), pp. 14-37.

Nonaka, I. and Takeuchi, H. (1995) The Knowledge-Creating Company: How Japanese Companies Create the Dynamics of Innovation, New York: Oxford University Press.

Pedler, M., Burgoyne, J. and Boydell, T. (1991) The learning company : a strategy for sustainable development, London: McGraw-Hill.

Polanyi, M. (1966) Den tause dimensjonen, New York: Doubleday.

Polanyi, M. (1967) The tacit dimension, Anchor Books, Garden City, N. Y: Doubleday.

Priniski, S. J., Hecht, C. A. and Harackiewicz, J. M. (2018) Making Learning Personally Meaningful: A New Framework for Relevance Research. The Journal of Experimental Education, 86(1), pp. 11-29.

Raelin, J. A. (2002) "I Dont Have Time to Think!" versus the Art of Reflective Practice. Reflections: The SoL Journal, 4(1), pp. 66-79.

Raelin, J. A. (2012) The manager as facilitator of dialogue. . Organization, 20(6), pp. 818-839.

Remenyi, D. (2012) Case Study Research : The Quick Guide Series, Case Study Research, Reading: Academic Conferences Publishing International.

Rhoades, L. and Eisenberger, R. (2002) Perceived Organizational Support: A Review of the Literature. Journal of Applied Psychology, 87(4), pp. 698-714.

Rogers, C. R. (1969) Freedom to learn, Colombus, Ohio: Merrill.

Schön, D. A. (1987) Educating the reflective practitioner, San Francisco, Calif.: Jossey-Bass.

Schön, D. A. (1991) The reflective practitioner : how professionals think in action, Aldershot: Avesbury.

Senge, P. M. (1992) The fifth discipline : the art and practice of the learning organization, London: Century Business.

Verpoorten, D., Westera, W. and Specht, M. (2012) Using reflection triggers while learning in an online course. Br. J. Educ. Technol., 43(6), pp. 1030-1040.

Vold, T. (2011) Being ready for emergencies- innovative approaces to fostering learning in and between organizations. in Sience, S. f. D. a. P., (ed.) SDPS,Jeju Island, South Corea: SDPS.

Wigfield, A. and Eccles, J. (2000) Expectancy-value theory of achievement motivation. Contemp. Educ. Psychol., 25(1), pp. 68-81. 